SANTINI, Maria Carolina. O pacote anticorrupção e o debate sobre sua constitucionalidade. Revista Eletrônica Direito e Política, Programa de Pós-Graduação Stricto Sensu em Ciência Jurídica da UNIVALI, Itajaí, v.12, n.3, $3^{\circ}$ quadrimestre de 2017. Disponível em: www.univali.br/direitoepolitica - ISSN 1980-7791

\title{
O PACOTE ANTICORRUPÇÃO E O DEBATE SOBRE SUA CONSTITUCIONALIDADE
}

\author{
THE ANTI-CORRUPTION PACKAGE AND THE DEBATE ON ITS \\ CONSTITUTIONALITY
}

Maria Carolina Santini P. C. ${ }^{1}$

SUMÁRIO: Introdução; 1 A primeira medida contra a corrupção: Prevenção à Corrupção, Transparência e Proteção à Fonte de Informação; 1.1 Teste de Integridade; $1.2 \mathrm{O}$ Informante Confidencial; $2 \mathrm{~A}$ segunda medida anticorrupção: Criminalização do Enriquecimento Ilícito de Agentes Públicos; 3 A terceira medida: Aumento das Penas e Crime Hediondo para a Corrupção de Altos Valores; 4 A quarta medida contra a corrupção: Eficiência dos Recursos no Processo Penal; 5 A quinta medida contra a corrupção: Celeridade nas Ações de Improbidade Administrativa; Considerações finais; Referências das fontes citadas

\section{RESUMO}

Este artigo apresenta as cinco primeiras medidas do pacote anti-corrupção e comentários a elas pertinentes, expondo o confronto, de membros do Ministério Público e advogados criminalistas. A corrupção na política brasileira suscitou manifestações públicas, asseverando a inconformidade da população, com ênfase nos prejuízos causados ao patrimônio público. Tal entrave tem sido enfrentado pelo Ministério Público Federal que, para tanto, apresentou como instrumento jurídico um conjunto de recomendações denominadas Dez Medidas Contra a Corrupção, o qual inaugura polêmica nacional. O documento acarreta comentários críticos em relação à sua constitucionalidade.

PALAVRAS-CHAVE: Corrupção; Ministério Público Federal; Pacote Anticorrupção

\footnotetext{
${ }^{1}$ Laureada em Direito pela Pontifícia Universidade Católica do Rio Grande do Sul (PUC-RS). Porto Alegre, RS, Brasil. Mestranda em Filosofia na PUC-RS, bolsista integral da CAPES. Orientador: Professor Doutor Nythamar de Oliveira. Pós-Graduanda em Direito Público na Universidade Cândido Mendes (UCAM-RJ). Advogada. Foi Bolsista do Conselho Nacional de Desenvolvimento Científico e Tecnológico (CNPq), orientanda do Professor Doutor Fabio Roberto D'Avila. Investigadora atuante nas áreas de: Direito Penal, Criminologia e Filosofia do Direito. Participante de diversos grupos de pesquisa. Membro do Grupo de Estudos e Pesquisa em Criminologia (GEPCrim), sob coordenação do Professor Doutor Álvaro Filipe Oxley da Rocha, vinculado ao Programa de Pós Graduação em Criminologia (PPGCrim) da Pontifícia Universidade Católica do Rio Grande do Sul (PUC-RS). Possui Curso de Argumentação Jurídica (2015); Curso Superior de Complementação de Estudos em Linguagem e Comunicação para a Área Jurídica (2013); Extensão Universitária em Filosofia e Direito (2013); Grupo de Estudos de Teoria Geral do Processo Civil (2013); Extensão Universitária em Violência: Aspectos Psicológicos, Biológicos e Sociais (2012). E-mail: maria.cunha.001@acad.pucrs.br
} 
SANTINI, Maria Carolina. O pacote anticorrupção e o debate sobre sua constitucionalidade. Revista Eletrônica Direito e Política, Programa de Pós-Graduação Stricto Sensu em Ciência Jurídica da UNIVALI, Itajaí, v.12, n.3, $3^{\circ}$ quadrimestre de 2017. Disponível em: www.univali.br/direitoepolitica - ISSN 1980-7791

\section{ABSTRACT}

This article presents the first five anti-corruption measures and comments on them, exposing the confrontation, of prosecutors and criminal lawyers in the controversy over the object, relating critical comments regarding the content. Corruption to brazilian politics has aroused public manifestations, ratifying the nonconformity of the population, with emphasis on the damages caused to the public patrimony. Such obstacles has been faced by the Federal Prosecution Public Service, who presented a legal instrument, a set of guidelines called Ten Measures Against Corruption, which inaugurated a national controversy. The document raises critical comments regarding its constitutionality.

KEYWORDS: Corruption; Federal Prosecution Public Service; Anti-Corruption Package

\section{INTRODUÇÃO}

O presente escrito abarca as Dez Medidas Contra a Corrupção, ou pacote anticorrupção, alternativas ofertadas pelo Ministério Público Federal que projeta seu papel no combate à corrupção em campanha nacional na qual fornece requisitos para possibilitar a diminuição da corrupção no Brasil.

O objetivo do artigo é expor os argumentos de procuradores da república e advogados criminalistas a respeito desse tema, defendendo a sua constitucionalidade ou inconstitucionalidade. Para tanto, parte-se da revisão bibliográfica, reproduzindo os entendimentos contrários e favoráveis às medidas interpeladas. Este trabalho trata das medidas originalmente propostas, e por limitações de espaço, da primeira à quinta. As medidas seguintes serão tratadas em artigo subsequente.

Posto isso, inicia-se com a primeira medida Prevenção à corrupção, transparência e proteção à fonte de informação, a qual se desmembra em duas figuras, nas subseções: Teste de integridade e $O$ informante confidencial. A seguir, expõe-se a segunda medida, denominada Criminalização do enriquecimento ilícito de agentes públicos. A terceira seção aborda o Aumento das penas e crime hediondo para a corrupção de altos valores. A penúltima seção propõe argumentos relacionados à quarta medida: Eficiência dos recursos no processo penal. A última seção trata da quinta medida, a Celeridade nas ações de improbidade administrativa. 
SANTINI, Maria Carolina. O pacote anticorrupção e o debate sobre sua constitucionalidade. Revista Eletrônica Direito e Política, Programa de Pós-Graduação Stricto Sensu em Ciência Jurídica da UNIVALI, Itajaí, v.12, n.3, $3^{\circ}$ quadrimestre de 2017. Disponível em: www.univali.br/direitoepolitica - ISSN 1980-7791

\section{A PRIMEIRA MEDIDA CONTRA A CORRUPÇÃO: PREVENÇÃO À CORRUPÇÃO, TRANSPARÊNCIA E PROTEÇÃO À FONTE DE INFORMAÇÃO}

A primeira medida é relativa à prevenção da corrupção, transparência e proteção à fonte de informação, na qual se desmembram duas figuras, quais sejam: o teste de integridade e o informante confidencial, a seguir destacados. Primeiramente, apresenta-se $o$ teste de integridade.

\subsection{TESTE DE INTEGRIDADE}

Em relação ao teste de integridade, Calabrich ${ }^{2}$ afirma que se trata de criar uma oportunidade camuflada para a prática de um ilícito, para cotejar: "se há predisposição ao ato ilícito e, concomitantemente, se essa predisposição, efetivamente testada, mediante a encenação de uma situação concreta, levará este funcionário a praticar a conduta ímproba." Aplicado esse teste, seus resultados poderão ser utilizados para instruir tanto um processo administrativo quanto processos ou investigações criminais (policiais ou do Ministério Público) e cíveis (inquéritos civis).

A respeito do art. $2^{\circ}$ da proposta 6 , a qual trata sobre a administração pública, "poderá, e os órgãos policiais deverão, submeter os agentes públicos a testes de integridade aleatórios ou dirigidos, cujos resultados poderão ser usados para fins disciplinares, bem como para a instrução de ações cíveis, inclusive a de improbidade administrativa, e criminais", afirma ${ }^{3}$ que nesse artigo é esclarecido "um dos principais focos de aplicação do teste de integridade é a conduta de policiais, que, pela particular gravidade da atividade que desempenham e pelo potencial de afetação a direitos fundamentais - como os de cidadãos sujeitos a abordagens policiais - precisaria de fiscalização constante e rigorosa. Mas não somente policiais poderiam ser fiscalizados pelo instrumento: qualquer agente

2 CALABRICH, Bruno. Teste de integridade: aplicação, críticas e constitucionalidade. Disponível em: http://www.dezmedidas.mpf.mp.br/apresentacao/artigos/teste-de-integridadebruno-calabrich.pdf/view. Acesso em: 29 out. 2016, p.2.

3 CALABRICH, Bruno. Teste de integridade: aplicação, críticas e constitucionalidade. Disponível em: http://www.dezmedidas.mpf.mp.br/apresentacao/artigos/teste-de-integridadebruno-calabrich.pdf/view. Acesso em: 29 out. 2016, p.2. 
SANTINI, Maria Carolina. O pacote anticorrupção e o debate sobre sua constitucionalidade. Revista Eletrônica Direito e Política, Programa de Pós-Graduação Stricto Sensu em Ciência Jurídica da UNIVALI, Itajaí, v.12, n.3, $3^{\circ}$ quadrimestre de 2017. Disponível em: www.univali.br/direitoepolitica - ISSN 1980-7791

público poderia ser submetido aos testes, que "serão realizados preferencialmente pela Corregedoria, Controladoria, Ouvidoria ou órgão congênere de fiscalização e controle" (art. $\left.4^{\circ}\right) .^{4}$

Entretanto, o autor ${ }^{5}$ aponta que há restrições na aplicação dos testes de integridade, não podendo ser aplicados indiscriminadamente: devem estar embasados em uma investigação em curso, ou, pelo menos, em informações de inteligência que indiquem possível prática de atos de corrupção em determinados grupo de funcionários públicos. Calabrich ${ }^{6}$ exprime que o teste "deve ser devidamente registrado e documentado pela autoridade responsável pela execução da medida - por gravação audiovisual ou por qualquer outro método (arts. $5^{\circ}$ e 10)."

Para Strec 7, o termo "pacote" tem teleologia juspunitiva, com inconstitucionalidades, e violações de direitos, ao que denomina de "eugenia cívica": o agente público deve se submeter a testes que apontem se é propenso a cometer crimes. Caso positivo, questiona que seria meio idôneo de prova, independentemente que o acusado a tenha produzido contra si próprio. Acrescenta se seria aplicado em concursos para juiz e procurador, bem como na indicação de ministros, os quais são agentes públicos. Assim, o autor ${ }^{8}$ afirma que tais medidas retroagem mais de um milênio ao limitar "a possibilidade de pedido liminar em habeas corpus."

Afirma $^{9}$ ainda que o "pensamento mágico - corrupção terá pena maior que

${ }^{4}$ CALABRICH, Bruno. Teste de integridade: aplicação, críticas e constitucionalidade. Disponível em: http://www.dezmedidas.mpf.mp.br/apresentacao/artigos/teste-de-integridadebruno-calabrich.pdf/view. Acesso em: 29 out. 2016, p.2.

${ }^{5}$ CALABRICH, Bruno. Teste de integridade: aplicação, críticas e constitucionalidade. p.3-4.

${ }^{6}$ CALABRICH, Bruno. Teste de integridade: aplicação, críticas e constitucionalidade. Disponível em: http://www.dezmedidas.mpf.mp.br/apresentacao/artigos/teste-de-integridadebruno-calabrich.pdf/view. Acesso em: 29 out. 2016, p.3-4.

7 STRECK, Lenio Luiz. Lenio Streck: pacote retroage mais de mil anos. Zero Hora. Porto Alegre. 28/02/2016. Disponível em: http://zh.clicrbs.com.br/rs/opiniao/noticia/2016/02/lenio-streckpacote-retroage-mais-de-mil-anos-4984832.html. Acesso em: 19 set. 2016.

8 STRECK, Lenio Luiz. Lenio Streck: pacote retroage mais de mil anos. Zero Hora.

9 STRECK, Lenio Luiz. Lenio Streck: pacote retroage mais de mil anos. Zero Hora. 
SANTINI, Maria Carolina. O pacote anticorrupção e o debate sobre sua constitucionalidade. Revista Eletrônica Direito e Política, Programa de Pós-Graduação Stricto Sensu em Ciência Jurídica da UNIVALI, Itajaí, v.12, n.3, $3^{\circ}$ quadrimestre de 2017. Disponível em: www.univali.br/direitoepolitica - ISSN 1980-7791

homicídio. Código Penal reduzido a pó. O pacote também cria o "informante C

0

$\mathrm{n}$

$\mathrm{f}$

i

d

e

$\mathrm{n}$

$\mathrm{C}$

a Streck ${ }^{11}$ aponta que o teste de integridade remete ao fator que denomina "Minority Report", título de um filme ficcional futurista, em que o Estado alcança o extermínio dos assassinatos, com uma divisão pré-crime, na qual o futuro culpado é identificado, preso e punido antes que o crime ocorra; e comparando, afirma que a proposta do MPF seria algo similar. O autor ${ }^{12}$ denomina de "eugenia cívica": por meio do pacote "o agente público deve se submeter a testes que apontem se é propenso a cometer crimes". Ressalta a observação do MPF de que o teste em comento não pode ser feito para reproduzir "uma tentação desmedida, a qual poderia levar uma pessoa honesta a se corromper". Traduz ${ }^{13}$ com uma provocação perguntando se seria melhor para o corrupto propinas mais altas, que indubitavelmente serviriam de alegação para uma "tentação desmedida". Ou se

V

${ }^{10}$ STRECK, Lenio Luiz. O pacote anticorrupção do Ministério Público e o fator Minority Report. Senso incomum. Conjur. 03/03/2016. Disponível em: http://www.conjur.com.br/2016-mar03/senso-incomum-pacote-anticorrupcao-mpf-fator-minority-report. Acesso em: 19 set. 2016.

${ }_{11}$ STRECK, Lenio Luiz. O pacote anticorrupção do Ministério Público e o fator Minority Report. Senso incomum. Conjur. 03/03/2016. Disponível em: http://www.conjur.com.br/2016-mar03/senso-incomum-pacote-anticorrupcao-mpf-fator-minority-report. Acesso em: 19 set. 2016. $\mathrm{P}$

12 STRECK, Lenio Luiz. O pacote anticorrupção do Ministério Público e o fator Minority Report. Senso incomum. Conjur. 03/03/2016. Disponível em: http://www.conjur.com.br/2016-mar03/senso-incomum-pacote-anticorrupcao-mpf-fator-minority-report. Acesso em: 19 set. 2016.

$r_{13}$ STRECK, Lenio Luiz. O pacote anticorrupção do Ministério Público e o fator Minority Report. Senso incomum. Conjur. 03/03/2016. Disponível em: http://www.conjur.com.br/2016-mar03/senso-incomum-pacote-anticorrupcao-mpf-fator-minority-report. Acesso em: 19 set. 2016.

C 
SANTINI, Maria Carolina. O pacote anticorrupção e o debate sobre sua constitucionalidade. Revista Eletrônica Direito e Política, Programa de Pós-Graduação Stricto Sensu em Ciência Jurídica da UNIVALI, Itajaí, v.12, n.3, $3^{\circ}$ quadrimestre de 2017. Disponível em: www.univali.br/direitoepolitica - ISSN 1980-7791

haveria uma "medida" da tentação "desmedida". O autor ${ }^{14}$ questiona de significa que "uma pessoa honesta é honesta só até certo ponto". Assim, contemplar-se-ia o crime antes da sua existência, por meio de "precogs" (informações por précognição).

A seguir, trata-se do informante confidencial como proteção da fonte de informação.

\subsection{O INFORMANTE CONFIDENCIAL}

Outra importante figura, na proposta, é o denominado Informante Confidencial. Sobre este, Dallagnol ${ }^{15}$ explica que o "informante revela informação relevante para investigação e processamento de crimes. É confidencial quando o Ministério Público ou a polícia conhece sua identidade", mas não deseja revelar para o investigado ou réu, ou para o público, justificando o segredo com base no interesse público. Diferentemente do informante anônimo, este é identificado. Ademais, não é chamado como testemunha, sendo excluída a hipótese de testemunha sem rosto. O informante poderia ser criminoso ou inocente.

A utilização de informantes confidenciais abrange três aspectos: "confidencialidade da fonte; valor probatório; e abrangência e consequências da revisão recursal", que estão interconectados no sistema brasileiro comparado com o norteamericano.

O autor $^{16}$ analisa a possibilidade de contribuição para o sistema pátrio em razão de diversos fatores, tais como o poder econômico dos criminosos, com infiltração

\footnotetext{
14 STRECK, Lenio Luiz. O pacote anticorrupção do Ministério Público e o fator Minority Report. Senso incomum. Conjur. 03/03/2016. Disponível em: http://www.conjur.com.br/2016-mar03/senso-incomum-pacote-anticorrupcao-mpf-fator-minority-report. Acesso em: 19 set. 2016.

15 DALLAGNOL, Deltan Martinazzo. Informantes confidenciais e anônimos: perspectivas para atuação mais eficiente do Estado a partir de uma análise comparativa do tratamento jurídico nos EUA e no Brasil. In: CAMBI, Eduardo; GUARAGNI, Fábio André (org). Ministério Público e princípio da proteção eficiente. São Paulo: Almedina, 2016, p.40.

16 DALLAGNOL, Deltan Martinazzo. Informantes confidenciais e anônimos: perspectivas para atuação mais eficiente do Estado a partir de uma análise comparativa do tratamento jurídico nos EUA e no Brasil. In: CAMBI, Eduardo; GUARAGNI, Fábio André (org). Ministério Público e princípio da proteção eficiente. São Paulo: Almedina, 2016, p.40.
} 
SANTINI, Maria Carolina. O pacote anticorrupção e o debate sobre sua constitucionalidade. Revista Eletrônica Direito e Política, Programa de Pós-Graduação Stricto Sensu em Ciência Jurídica da UNIVALI, Itajaí, v.12, n.3, $3^{\circ}$ quadrimestre de 2017. Disponível em: www.univali.br/direitoepolitica - ISSN 1980-7791

na estrutura estatal ou complexidade de técnicas empregadas, além da dificuldade probatória do delito e sua baixa visibilidade ${ }^{17}$. Desse modo, declara a busca por melhoria e eficiência no sistema brasileiro.

Trata-se de publicidade: nos EUA, país com forte tradição de acordos de delação, a confidencialidade é tratada como inerente ao direito potestativo do governo. Em casos internacionais julgados pela Suprema Corte americana, trazidos pelo autor ${ }^{18}$, obteve-se que as provas trazidas e a confiabilidade do informante confidencial é maior do que as do informante anônimo.

O tema Informantes Confidenciais é escasso na literatura e na prática jurídica. Apesar da importância na persecução criminal, a exclusão da prova ilícita é um dos fatores desencoraja o seu uso. ${ }^{19} \mathrm{O}$ STF tem admitido o uso denúncia anônima antes da instauração do inquérito policial ${ }^{20}$. No Brasil apesar de ser incomum o uso de informantes confidenciais, estes tem sido comumente utilizados como informantes anônimos ${ }^{21}$.

Gualtieri e Cerqueira ${ }^{22}$ conceitualizam o informante, o qual, servidor público ou não, seria aquele que leva ao conhecimento do Ministério Público ou de outros

17 DALLAGNOL, Deltan Martinazzo. Informantes confidenciais e anônimos: perspectivas para atuação mais eficiente do Estado a partir de uma análise comparativa do tratamento jurídico nos EUA e no Brasil. In: CAMBI, Eduardo; GUARAGNI, Fábio André (org). Ministério Público e princípio da proteção eficiente. São Paulo: Almedina, 2016, p.41.

18 DALLAGNOL, Deltan Martinazzo. Informantes confidenciais e anônimos: perspectivas para atuação mais eficiente do Estado a partir de uma análise comparativa do tratamento jurídico nos EUA e no Brasil. In: CAMBI, Eduardo; GUARAGNI, Fábio André (org). Ministério Público e princípio da proteção eficiente. São Paulo: Almedina, 2016, p.47-48.

19 DALLAGNOL, Deltan Martinazzo. Informantes confidenciais e anônimos: perspectivas para atuação mais eficiente do Estado a partir de uma análise comparativa do tratamento jurídico nos EUA e no Brasil. In: CAMBI, Eduardo; GUARAGNI, Fábio André (org). Ministério Público e princípio da proteção eficiente. São Paulo: Almedina, 2016, p.50.

20 DALLAGNOL, Deltan Martinazzo. Informantes confidenciais e anônimos: perspectivas para atuação mais eficiente do Estado a partir de uma análise comparativa do tratamento jurídico nos EUA e no Brasil. In: CAMBI, Eduardo; GUARAGNI, Fábio André (org). Ministério Público e princípio da proteção eficiente. São Paulo: Almedina, 2016, p.53.

21 DALLAGNOL, Deltan Martinazzo. Informantes confidenciais e anônimos: perspectivas para atuação mais eficiente do Estado a partir de uma análise comparativa do tratamento jurídico nos EUA e no Brasil. In: CAMBI, Eduardo; GUARAGNI, Fábio André (org). Ministério Público e princípio da proteção eficiente. São Paulo: Almedina, 2016, p.57.

22 GUALTIERI, Lucas de Morais; CERQUEIRA, Marcelo Malheiros. Pelo MP: o informante confidencial como instrumento de combate à corrupção. Jota. 29/03/2016. Disponível em: http://jota.info/pelomp-o-informante-confidencial-como-instrumento-de-combate-corrupcao. Acesso em: 29 out. 2016. 
SANTINI, Maria Carolina. O pacote anticorrupção e o debate sobre sua constitucionalidade. Revista Eletrônica Direito e Política, Programa de Pós-Graduação Stricto Sensu em Ciência Jurídica da UNIVALI, Itajaí, v.12, n.3, $3^{\circ}$ quadrimestre de 2017. Disponível em: www.univali.br/direitoepolitica - ISSN 1980-7791

órgãos investigativos informações, sobre crimes ou atos de improbidade administrativa, as quais podem ser utilizadas para instaurar investigações ou para instrução das existentes. Há no processo penal pátrio a figura caracterizada como "informante anônimo", o qual tem sua identidade desconhecida.

No anteprojeto do MPF a proposta é pela regulamentação do denominado "informante confidencial", cujos dados são conhecidos, mas "mantidos de forma reservada pelo órgão destinatário das informações":

O anteprojeto estabelece tal figura a partir do artigo $1^{\circ}$. In verbis: "Art. $1^{0}$ Esta Lei disciplina, nos termos do art. 50, inciso XIV, da Constituição Federal, o sigilo da fonte da informação que deu causa à investigação relacionada à prática de atos de corrupção.

Art. $2^{\circ}$ Nas esferas administrativa, cível e criminal, poderá o Ministério Público resguardar o sigilo da fonte de informação que deu causa à investigação relacionada à prática de ato de corrupção, quando se tratar de medida essencial à obtenção dos dados ou à incolumidade do noticiante ou por outra razão de relevante interesse público, devidamente esclarecidas no procedimento investigatório respectivo.

Parágrafo único. O Ministério Público poderá arrolar agente público, inclusive policial, para prestar depoimento sobre o caráter e a confiabilidade do informante confidencial, os quais deverão resguardar a identidade deste último, sob pena de responsabilidade.

Art. 30 Ninguém poderá ser condenado apenas com base no depoimento prestado por informante confidencial.

Art. $4^{\circ}$ No caso do conhecimento da identidade do informante confidencial ser essencial ao caso concreto, juiz ou tribunal, ao longo da instrução ou em grau recursal, poderá determinar ao Ministério Público que opte entre a revelação da identidade daquele ou a perda do valor probatório do depoimento prestado, ressalvada a validade das demais provas produzidas no processo.

Art. $5^{\circ}$ Comprovada a falsidade dolosa da imputação feita pelo informante confidencial, será revelada a sua identidade e poderá ele responder pelos crimes de denunciação caluniosa ou de falso testemunho, sem prejuízo das ações cíveis cabíveis. 
SANTINI, Maria Carolina. O pacote anticorrupção e o debate sobre sua constitucionalidade. Revista Eletrônica Direito e Política, Programa de Pós-Graduação Stricto Sensu em Ciência Jurídica da UNIVALI, Itajaí, v.12, n.3, $3^{\circ}$ quadrimestre de 2017. Disponível em: www.univali.br/direitoepolitica - ISSN 1980-7791

Art. $6^{\circ}$ Aplicam-se as disposições desta Lei, no que couber, à Lei no 12.846 , de $1^{\circ}$ de agosto de 2013."

O sigilo de sua identidade seria mantido no momento em que for crucial para atingir dados ou segurança do denunciante ou demais razões de interesse público no procedimento investigatório. A confidencialidade inclusive permaneceria após início da ação penal, com possibilidade de afastamento: por opção do parquet, caso seja determinante a revelação da identidade no caso concreto; se o juiz determinar "sob pena de perda do valor probatório do depoimento prestado" ou se houver comprovação de "falsidade dolosa da imputação feita pelo informante confidencial", com vedação expressa de condenação motivada puramente no depoimento, necessitando, assim, de outros meios de prova. ${ }^{23}$

Desse modo, o informante confidencial difere da testemunha, já que suas informações teriam valor limitado, no que tange à prova. Isso se dá devido ao fato de a defesa não poder confrontar seus informes de modo exauriente. Segundo os autores $^{24}$, o principal fundamento constitucional, artigo 50, XIV, CF/88, assegura o sigilo da fonte de informação, ressaltando a árdua incumbência para os órgãos investigação, de comprovar os atos de corrupção, tidos como crimes contra a Administração Pública, e atos de improbidade administrativa, devido aos ilícitos dos corruptos ocorrerem às escondidas de terceiros, havendo por isso maior dificuldade probatória, com modus operandi complexo e sofisticado, o que prejudica a investigação.

Por isso, o informante confidencial se torna figura indispensável na persecução de tais crimes. A figura se justificaria, dado o ônus pessoal que traz consigo por revelar o crime em meio ao "código de silêncio" que vigora nesse meio, implicando consequências para seu rompimento, a exemplo da corrupção policial, tais como:

\footnotetext{
23 GUALTIERI, Lucas de Morais; CERQUEIRA, Marcelo Malheiros. Pelo MP: o informante confidencial como instrumento de combate à corrupção. Jota. 29/03/2016. Disponível em: http://jota.info/pelomp-o-informante-confidencial-como-instrumento-de-combate-corrupcao. Acesso em: 29 out. 2016.

24 GUALTIERI, Lucas de Morais; CERQUEIRA, Marcelo Malheiros. Pelo MP: o informante confidencial como instrumento de combate à corrupção. Jota. 29/03/2016. Disponível em: http://jota.info/pelomp-o-informante-confidencial-como-instrumento-de-combate-corrupcao. Acesso em: 29 out. 2016.
} 
SANTINI, Maria Carolina. O pacote anticorrupção e o debate sobre sua constitucionalidade. Revista Eletrônica Direito e Política, Programa de Pós-Graduação Stricto Sensu em Ciência Jurídica da UNIVALI, Itajaí, v.12, n.3, $3^{\circ}$ quadrimestre de 2017. Disponível em: www.univali.br/direitoepolitica - ISSN 1980-7791

ostracismo, ameaças, danos à propriedade, inclusive violência. ${ }^{25}$

Os autores ${ }^{26}$ apontam para inconvenientes como a jurisprudência pátria do STJ e STF condicionar a admissibilidade de denúncia anônima com diligências preliminares corroborativas, cujo entendimento foi aplicado no Habeas Corpus no 137.349-SP, o qual anulou a Operação Castelo de Areia. Nesse viés, ainda que o informante disponha de dados concretos de ilícitos, as informações não poderiam ser utilizadas automaticamente. "Cabe ao Ministério Público, por outros meios, obter elementos que confirmem aqueles dados fornecidos". Segundo Medeiros, ${ }^{27}$ a preservação do sigilo da fonte de informação foi "um dos pilares das reformas adotadas em Hong Kong, tornando-o um dos mais famosos exemplos de combate à corrupção". A partir da "corrupção endêmica nos anos 1960, Hong Kong passou para a $17^{a}$ posição no ranking global de honestidade da Transparência Internacional". O slogan fulcral da fase inicial do processo de modificações foi justamente "reporte a corrupção". ${ }^{28}$ Afirma ${ }^{29}$ que não há incentivo suficiente da

$25 \mathrm{PUNCH}$, Maurice. Police corruption: desviance, accountability and reform in policing. New york/London: Routhledge, 2011, p.37 apud GUALTIERI, Lucas de Morais; CERQUEIRA, Marcelo Malheiros. Pelo MP: o informante confidencial como instrumento de combate à corrupção. Jota. 29/03/2016. Disponível em: http://jota.info/pelo-mp-o-informante-confidencial-como-instrumentode-combate-corrupcao. Acesso em: 29 out. 2016.

26 GUALTIERI, Lucas de Morais; CERQUEIRA, Marcelo Malheiros. Pelo MP: o informante confidencial como instrumento de combate à corrupção. Jota. 29/03/2016. Disponível em: http://jota.info/pelomp-o-informante-confidencial-como-instrumento-de-combate-corrupcao. Acesso em: 29 out. 2016.

27 MEDEIROS, Mário Alves. Preservação do sigilo da fonte em casos de corrupção: medida
necessária, constitucional correta.
http://www.dezmedidas.mpf.mp.br/apresentacao/artigos/sigilo-da-fonte-mario-alvesmedeiros.pdf., p.2.

28 Segundo a autora, houve recomendação da ONU aos seus Estados Partes, em 2003, de adoção de medidas para incentivar a sociedade a participar na prevenção e na luta contra a corrupção, inclusive por meio de "denúncias anônimas" (Convenção contra a corrupção, art. 13.2). "Os tribunais da Espanha, Alemanha e Itália, embora não admitam, seja alguém processado ou condenado apenas com base em informações anônimas, ressalvam a possibilidade, e, até mesmo, a necessidade de que os fatos reportados seriam investigados. O Tribunal Europeu de Direitos Humanos admite a ocultação da identidade de testemunhas (caso Lüdi v. Suíça e caso Kok v. Holanda) e, mais importante, admite a realização de investigações a partir de fontes confidenciais, não aceitando somente a condenação fundamentada apenas nos seus relatos. As cautelas adotadas na Europa estão todas contempladas na campanha das "10 Medidas contra a Corrupção" [...] tem se mostrado insuficiente. Ocorre que a mencionada Lei no 9.807/1999 protege apenas vítimas e testemunhas, mas não as pessoas que se dispõem a ser meros informantes". In: MEDEIROS, Mário Alves. Preservação do sigilo da fonte em casos de corrupção: medida necessária, constitucional e correta. Disponível em: http://www.dezmedidas.mpf.mp.br/apresentacao/artigos/sigilo-da-fonte-mario-alvesmedeiros.pdf., p. 2.

29 MEDEIROS, Mário Alves. Preservação do sigilo da fonte em casos de corrupção: medida necessária, constitucional e correta. Disponível em: 
SANTINI, Maria Carolina. O pacote anticorrupção e o debate sobre sua constitucionalidade. Revista Eletrônica Direito e Política, Programa de Pós-Graduação Stricto Sensu em Ciência Jurídica da UNIVALI, Itajaí, v.12, n.3, $3^{\circ}$ quadrimestre de 2017. Disponível em: www.univali.br/direitoepolitica - ISSN 1980-7791

participação da sociedade na luta contra a corrupção. É compreensível, para ela, que "poucos estejam dispostos a mudar de residência, abandonar seus empregos, romper laços com amigos e familiares ou alterar todos os seus documentos".

Há leitura de que "a utilização de relatos confidenciais pelo Poder Público seria imoral, em razão dos inúmeros abusos praticados no passado". Pondera a autora 30 que a História está repleta de arquétipos de abusos, baseados em denúncias anônimas. Entretanto, "a proposta embutida na campanha das Dez Medidas contra a Corrupção não contempla denúncias anônimas, mas apenas a simples preservação da identidade dos informantes".

Flavio Antonio da Cruz $^{31}$ explica que o representante do Ministério Público pode manter em sigilo absoluto a fonte de informação responsável pela deflagração da apuração criminal, no que tange à suspeita da prática de atos de corrupção, desde que isso seja essencial à obtenção de dados ou preservação da segurança do noticiante. O autor ${ }^{32}$ afirma ser inconstitucional, dada a vedação do anonimato, art. 50, IV, CF. o processo inquisitório que permitia a não identificação do confronto do acusado com o acusador. Aponta também para a existência, na legislação pátria, da proteção a informantes e testemunhas (Lei 9.807/99), e que os direitos fundamentais são inerentes ao devido processo.

Para $\mathrm{Cruz}^{33}$, com o impulso de melhorar a vida comunitária, não se pode reduzir direitos imprescindíveis, sendo que no Brasil o Estado está entre os motivadores dos problemas que afirma ter ânimo de solucionar, com chamados "bons

http://www.dezmedidas.mpf.mp.br/apresentacao/artigos/sigilo-da-fonte-mario-alvesmedeiros.pdf., p.4.

30 MEDEIROS, Mário Alves. Preservação do sigilo da fonte em casos de corrupção: medida necessária, constitucional e correta. Disponível em: http://www.dezmedidas.mpf.mp.br/apresentacao/artigos/sigilo-da-fonte-mario-alvesmedeiros.pdf., p.4.

${ }^{31}$ CRUZ, Flavio Antonio da. Teste de integridade e sigilo da fonte: exame crítico. Boletim do Instituto Brasileiro de Ciências Criminais, ano 23, no 277, 2015, p.5.

32 CRUZ, Flavio Antonio da. Teste de integridade e sigilo da fonte: exame crítico. Boletim do Instituto Brasileiro de Ciências Criminais, ano 23, no 277, 2015, p.5.

33 CRUZ, Flavio Antonio da. Teste de integridade e sigilo da fonte: exame crítico. Boletim do Instituto Brasileiro de Ciências Criminais, ano 23, no 277, 2015, p.6, grifo do autor. 
SANTINI, Maria Carolina. O pacote anticorrupção e o debate sobre sua constitucionalidade. Revista Eletrônica Direito e Política, Programa de Pós-Graduação Stricto Sensu em Ciência Jurídica da UNIVALI, Itajaí, v.12, n.3, $3^{\circ}$ quadrimestre de 2017. Disponível em: www.univali.br/direitoepolitica - ISSN 1980-7791

propósitos, autorizados em casos de suspeitas graves, incluindo desvio de recursos públicos, possam fortalecer o autoritarismo estatal, com tendência de tratar os cidadãos como cera mole na mão de inquisidores". Streck ${ }^{34}$ comenta que o Projeto de Lei n04.850/2016 é uma pretensão de legalizar o "denuncismo próprio de regimes autoritários, onde as pessoas incriminam vizinhos, colegas de trabalho, familiares, desafetos, etc., sem ter que mostrar o rosto para o denunciado".

Feitas as considerações sobre o informante confidencial e o teste de integridade, cabe a próxima medida, a qual retrata o enriquecimento sem causa, sinônimo de enriquecimento ilícito, como é denominado no Projeto de Lei no 4.850/2016:

\section{A SEgUNDA MEDIDA ANTICORRUPÇÃO: CRIMINALIZAÇÃO DO ENRIQUECIMENTO ILÍCITO DE AGENTES PÚBLICOS}

Pedro Jorge do Nascimento Costa ${ }^{35}$ informa que a Convenção das Nações Unidas contra a Corrupção, incorporada pelo Decreto no 5.687, de 31 de janeiro de 2006, prevê, em seu art. 20, que o Estado Parte "considerará a possibilidade de adotar as medidas legislativas e de outras índoles que sejam necessárias para qualificar como delito, quando cometido intencionalmente, o enriquecimento ilícito".

Para Panoeiro ${ }^{36}$, a Convenção Interamericana (Artigo IX) e a Convenção das Nações Unidas contra a Corrupção (Artigo 20), do mesmo modo, "trouxeram a indicação para que os signatários introduzissem em seus ordenamentos o delito de enriquecimento ilícito". A Convenção Interamericana contra a Corrupção (Decreto no 4.410/2002), no artigo IX, sobre o enriquecimento ilícito, expõe:

Sem prejuízo de sua Constituição e dos princípios fundamentais de seu ordenamento jurídico, os Estados Partes

34 STRECK, Lenio Luiz. O pacote anticorrupção do Ministério Público e o fator Minority Report. Senso incomum. Conjur. 03/03/2016. Disponível em: http://www.conjur.com.br/2016-mar03/senso-incomum-pacote-anticorrupcao-mpf-fator-minority-report. Acesso em: 19 set. 2016.

35 COSTA, Pedro Jorge do Nascimento. O crime de enriquecimento ilícito: compatibilidade com o ordenamento jurídico. Disponível em: http://www.dezmedidas.mpf.mp.br/apresentacao/artigos/crime-de-enriquecimento-ilicito-pedrojorge.pdf/view. Acesso em: 29 out. 2016, p.2.

36 PANOEIRO, José Maria. O delito de enriquecimento ilícito como estratégia para o combate à corrupção: considerações, críticas e reflexões político-criminais. Disponível em: http://www.dezmedidas.mpf.mp.br/apresentacao/artigos/crime-de-enriquecimento-ilicito-josepanoeiro.pdf/view. Acesso em: 29 out. 2016, p.5. 
SANTINI, Maria Carolina. O pacote anticorrupção e o debate sobre sua constitucionalidade. Revista Eletrônica Direito e Política, Programa de Pós-Graduação Stricto Sensu em Ciência Jurídica da UNIVALI, Itajaí, v.12, n.3, $3^{\circ}$ quadrimestre de 2017. Disponível em: www.univali.br/direitoepolitica - ISSN 1980-7791

que ainda não o tenham feito adotarão as medidas necessárias para tipificar como delito em sua legislação o aumento do patrimônio de um funcionário público que exceda de modo significativo sua renda legítima durante o exercício de suas funções e que não possa justificar razoavelmente. Entre os Estados Partes que tenham tipificado o delito de enriquecimento ilícito, este será considerado um ato de corrupção para os propósitos desta Convenção. O Estado Parte que não tenha tipificado o enriquecimento ilícito prestará a assistência e cooperação previstas nesta Convenção relativamente a este delito, na medida em que o permitirem as suas leis.

O autor $^{37}$ traz a Convenção das Nações Unidas contra a Corrupção (Decreto no $5.687 / 2006)$, em seu artigo 20 , que trata do enriquecimento ilícito:

Com sujeição a sua constituição e aos princípios fundamentais de seu ordenamento jurídico, cada Estado Parte considerará a possibilidade de adotar as medidas legislativas e de outras índoles que sejam necessárias para qualificar como delito, quando cometido intencionalmente, o enriquecimento ilícito, ou seja, o incremento significativo do patrimônio de um funcionário público relativo aos seus ingressos legítimos que não podem ser razoavelmente justificados por ele.

Panoeiro ${ }^{38}$ afirma que não se trata de concordar ou discordar de qualquer espécie de "agremiação partidária ou de se seguir uma ou outra vertente ideológica, mas, tão somente, de se afirmar que a coisa pública deve ser gerida em prol da coletividade, e não como meio para o enriquecimento injustificado de uma minoria".

Costa ${ }^{39}$ comenta que, não bastante, a Convenção Interamericana contra a Corrupção, internalizada pelo Decreto no 4.410/2002, dispõe no art. IX que os

37 PANOEIRO, José Maria. 0 delito de enriquecimento ilícito como estratégia para o combate à corrupção: considerações, críticas e reflexões político-criminais. Disponível em: http://www.dezmedidas.mpf.mp.br/apresentacao/artigos/crime-de-enriquecimento-ilicito-josepanoeiro.pdf/view. Acesso em: 29 out. 2016, p.6.

38 PANOEIRO, José Maria. 0 delito de enriquecimento ilícito como estratégia para o combate à corrupção: considerações, críticas e reflexões político-criminais. Disponível em: http://www.dezmedidas.mpf.mp.br/apresentacao/artigos/crime-de-enriquecimento-ilicito-josepanoeiro.pdf/view. Acesso em: 29 out. 2016, p.4.

39 COSTA, Pedro Jorge do Nascimento. O crime de enriquecimento ilícito: compatibilidade com or ordenamento jurídico. $\quad$ Disponível $\quad$ em: 
SANTINI, Maria Carolina. O pacote anticorrupção e o debate sobre sua constitucionalidade. Revista Eletrônica Direito e Política, Programa de Pós-Graduação Stricto Sensu em Ciência Jurídica da UNIVALI, Itajaí, v.12, n.3, $3^{\circ}$ quadrimestre de 2017. Disponível em: www.univali.br/direitoepolitica - ISSN 1980-7791

Estados Partes "adotarão as medidas necessárias para tipificar como delito em sua legislação o aumento do patrimônio de um funcionário público que exceda de modo significativo sua renda legítima durante o exercício de suas funções e que não possa justificar razoavelmente."

O autor ${ }^{40}$ traz o direito comparado, países já criminalizam o enriquecimento ilícito, tais como: México, Nicarágua, Chile, Peru, Argentina, Colômbia, El Salvador, Hong Kong, China e França. A proposta do Ministério Público Federal é a inserção do art. 312-A ao Código Penal, que teria a seguinte redação sobre o Enriquecimento ilícito:

Art. 312-A. Adquirir, vender, emprestar, alugar, receber, ceder, possuir, utilizar ou usufruir, de maneira não eventual, bens, direitos ou valores cujo valor seja incompatível com os rendimentos auferidos pelo servidor público, ou por pessoa a ele equiparada, em razão de seu cargo, emprego, função pública ou mandato eletivo, ou auferidos por outro meio lícito:

Pena - prisão, de 3 (três) a 8 (oito anos), e confisco dos bens, se o fato não constituir elemento de crime mais grave.

A Medida no 2 difere da proposta de Novo Código Penal apenas pela "inclusão do verbo possuir e pela adoção do patamar de penas, constante do projeto que teve origem na CGU", distanciando-se do paradigma pretendido pela Comissão de Reforma do Código Penal ${ }^{41}$ que trata do Enriquecimento ilícito:

$\S 1^{0}$ Caracteriza-se o enriquecimento ilícito ainda que, observadas as condições do caput, houver amortização ou extinção de dívidas do servidor público, ou de quem a ele equiparado, inclusive por terceira pessoa.

jorge.pdf/view. Acesso em: 29 out. 2016, p.2.

40 COSTA, Pedro Jorge do Nascimento. O crime de enriquecimento ilícito: compatibilidade com o ordenamento jurídico. Disponível em: http://www.dezmedidas.mpf.mp.br/apresentacao/artigos/crime-de-enriquecimento-ilicito-pedrojorge.pdf/view. Acesso em: 29 out. 2016, p.2.

41 PANOEIRO, José Maria. O delito de enriquecimento ilícito como estratégia para o combate à corrupção: considerações, críticas e reflexões político-criminais. Disponível em: http://www.dezmedidas.mpf.mp.br/apresentacao/artigos/crime-de-enriquecimento-ilicito-josepanoeiro.pdf/view. Acesso em: 29 out. 2016, p.7. 
SANTINI, Maria Carolina. O pacote anticorrupção e o debate sobre sua constitucionalidade. Revista Eletrônica Direito e Política, Programa de Pós-Graduação Stricto Sensu em Ciência Jurídica da UNIVALI, Itajaí, v.12, n.3, $3^{\circ}$ quadrimestre de 2017. Disponível em: www.univali.br/direitoepolitica - ISSN 1980-7791

$\S 20$ As penas serão aumentadas de metade a dois terços se a propriedade ou a posse dos bens e valores for atribuída fraudulentamente a terceiras pessoas.

Luís Greco ${ }^{42}$ aponta que a pena é de 3 a 8 anos, para quem

adquirir, vender, emprestar, alugar, receber, ceder, possuir, utilizar ou usufruir, de maneira não eventual, bens, direitos ou valores cujo valor seja incompatível com os rendimentos auferidos pelo servidor público, ou por pessoa a ele equiparada, em razão de seu cargo, emprego, função pública ou mandato eletivo, ou auferidos por outro meio lícito.

Greco $^{43}$ afirma que o enriquecimento ilícito é tratado pelo Ministério Público Federal como prova indireta da corrupção. A medida se explica tendo em vista a dificuldade em punir as condutas pelo crime de corrupção. O MPF menciona a "Convenção das Nações Unidas contra a Corrupção (2004), da qual o Brasil é signatário". Nesse caso, argumenta ${ }^{44}$, haveria uma "pena de suspeita", contrariando princípios fundamentais do Direito Penal e Processual Penal, tais como o da "culpabilidade direito de ser condenado a punido apenas pelo cometimento de seus atos - e seu correlato, a presunção de inocência". Assim, aponta Greco ${ }^{45}$ que "a condenação e punição não são causadas por enriquecer, mas por ter praticado atos de corrupção ou de peculato".

Os mencionados princípios violados manifestam-se pela não comprovação desses atos. Contra tal argumento, o MPF alega que baseado na experiência compartilhada, caso a acusação prove "a existência de renda discrepante da fortuna acumulada e, além disso, nem uma investigação cuidadosa nem investigada apontam a existência provável de fontes lícitas, pode-se concluir que se trata de renda ilícita". Greco ${ }^{46}$ acusa que não haveria necessidade de se criar

42 GRECO, Luís. Reflexões provisórias sobre o crime de enriquecimento ilícito. Boletim do Instituto Brasileiro de Ciências Criminais, ano 23, no 277, 2015, p.7.

43 GRECO, Luís. Reflexões provisórias sobre o crime de enriquecimento ilícito. Boletim do Instituto Brasileiro de Ciências Criminais, ano 23, no 277, 2015, p.7.

44 GRECO, Luís. Reflexões provisórias sobre o crime de enriquecimento ilícito. Boletim do Instituto Brasileiro de Ciências Criminais, ano 23, no 277, 2015, p.7.

45 GRECO, Luís. Reflexões provisórias sobre o crime de enriquecimento ilícito. Boletim do Instituto Brasileiro de Ciências Criminais, ano 23, no 277, 2015, p.7.

46 GRECO, Luís. Reflexões provisórias sobre o crime de enriquecimento ilícito. Boletim do Instituto Brasileiro de Ciências Criminais, ano 23, no 277, 2015, p.7. 
SANTINI, Maria Carolina. O pacote anticorrupção e o debate sobre sua constitucionalidade. Revista Eletrônica Direito e Política, Programa de Pós-Graduação Stricto Sensu em Ciência Jurídica da UNIVALI, Itajaí, v.12, n.3, $3^{\circ}$ quadrimestre de 2017. Disponível em: www.univali.br/direitoepolitica - ISSN 1980-7791

outro dispositivo para fundamentar a decisão judicial pelo art.317, caput, do CP pelo crime de corrupção passiva. Por isso, tal medida, segundo ele, é supérflua. Para o Ministério Público Federal, o enriquecimento ilícito revela um agir:

imoral e ilegal de servidor público, de quem se espera um comprometimento mais significativo com a lei do que se espera do cidadão comum. Há aqui um desvalor no tocante à discrepância patrimonial, não raro oculta ou disfarçada, de um agente público sujeito a regras de escrutínio, transparência e lisura.

O desvalorado não seria o enriquecimento ilícito, e sim a sua revelação. Greco ${ }^{47}$ aponta para a problemática da prova indireta. Tais ideias, remete o autor que, deveriam ser precedidas ao que ele chama de esforço ativista-populista de angariamento de assinaturas. Para o autor"48, o corrupto "corrompe essa ideia, trai aquilo que justifica a existência da própria instituição a que se vale. Ele não se orienta segundo o interesse público, e sim segundo caprichos particulares; ele não serve, mas usufrui". Há outro problema da formulação concreta do tipo, do qual carece o Ministério Público Federal, de teoria sobre o desvalor do comportamento a ser criminalizado. A proposta do órgão público seria infundada e apressada. Conclui ${ }^{49}$ que a facilitação de prova é policialesca, incompatível com os princípios da presunção de inocência bem como o da culpabilidade. Ademais, de eficácia duvidosa. Poder-se-ia fundamentá-la partir do princípio da proteção de bens jurídicos, "um desvalor autônomo da conduta" em voga, justificando a tese da criminalização. Ocorre que facilitação de provas deveria ser melhor avaliada, inclusive pela noção de ultima ratio, e pelo fato de o direito penal já ser bastante abrangente. Nesse sentido, portanto, a coleta de assinaturas não dispensa a justificativa.

Streck ${ }^{50}$ explica o enriquecimento ilícito de agentes públicos: "considera-se

47 GRECO, Luís. Reflexões provisórias sobre o crime de enriquecimento ilícito. Boletim do Instituto Brasileiro de Ciências Criminais, ano 23, no 277, 2015, p.7.

48 GRECO, Luís. Reflexões provisórias sobre o crime de enriquecimento ilícito. Boletim do Instituto Brasileiro de Ciências Criminais, ano 23, no 277, 2015, p.7.

49 GRECO, Luís. Reflexões provisórias sobre o crime de enriquecimento ilícito. Boletim do Instituto Brasileiro de Ciências Criminais, ano 23, no 277, 2015, p.7.

50 STRECK, Lenio Luiz. O pacote anticorrupção do Ministério Público e o fator Minority Report. 
SANTINI, Maria Carolina. O pacote anticorrupção e o debate sobre sua constitucionalidade. Revista Eletrônica Direito e Política, Programa de Pós-Graduação Stricto Sensu em Ciência Jurídica da UNIVALI, Itajaí, v.12, n.3, $3^{\circ}$ quadrimestre de 2017. Disponível em: www.univali.br/direitoepolitica - ISSN 1980-7791

situação de enriquecimento ilícito quando houver amortização ou extinção de dívidas do servidor público por terceiro". E comenta ${ }^{51}$ que é "tão surreal que se o próprio pai paga dívida de filho servidor público endividado, pode ser processado porque é um terceiro enriquecendo ilicitamente o rebento". Nesse sentido, Souza52 ressaltou que foi a atuação dos membros do MPF que expôs a corrupção no sistema financeiro e a reação dos atingidos:

Considerando que as críticas visavam mais apoiar as propostas legislativas restritivas das atribuições ministeriais relacionadas com a responsabilização de autoridades do que evidenciar eventuais excessos cometidos por alguns membros do MP (individualmente), verificavam evidências de que a sociedade brasileira adquiria sensação de que os crimes cometidos pelos "poderosos" não seriam ignorados.

O autor ${ }^{53}$ aponta para o fato que "pesquisadores demonstravam preocupação com o fato de funcionários não-eleitos intervirem em atos legitimados pelo voto popular, sustentaram que o arranjo decorria de um novo tipo de democracia", em que crescem "agências de fiscalização de todos os ramos do governo representavam a inserção crescente do direito na política em condições que não se encaixam facilmente ao clássico paradigma de separação de poderes". 54

Confrontando o parecer "e as limitações do Ministério Público no sistema de justiça

Senso incomum. Conjur. 03/03/2016. Disponível em: http://www.conjur.com.br/2016-mar03/senso-incomum-pacote-anticorrupcao-mpf-fator-minority-report. Acesso em: 19 set. 2016.

51 STRECK, Lenio Luiz. O pacote anticorrupção do Ministério Público e o fator Minority Report. Senso incomum. Conjur. 03/03/2016. Disponível em: http://www.conjur.com.br/2016-mar03/senso-incomum-pacote-anticorrupcao-mpf-fator-minority-report. Acesso em: 19 set. 2016.

52 SOUZA, Luciano Machado de. Abdicação de accountability para arquivamento de inquérito ou peças de informação de infração penal pelo procurador-geral da república: afetação das dimensões democrática e republicana do estado democrático de direito. Tese (Doutorado em Direito). Curitiba: UFPR, 2016, p.130.

53 SOUZA, Luciano Machado de. Abdicação de accountability para arquivamento de inquérito ou peças de informação de infração penal pelo procurador-geral da república: afetação das dimensões democrática e republicana do estado democrático de direito. Tese (Doutorado em Direito). Faculdade de Direito. Universidade Federal do Paraná. Curitiba: UFPR, 2016, p. 130 .

54 SOUZA, Luciano Machado de. Abdicação de accountability para arquivamento de inquérito ou peças de informação de infração penal pelo procurador-geral da república: afetação das dimensões democrática e republicana do estado democrático de direito. Tese (Doutorado em Direito). Faculdade de Direito. Universidade Federal do Paraná. Curitiba: UFPR, 2016, p. 130 . 
SANTINI, Maria Carolina. O pacote anticorrupção e o debate sobre sua constitucionalidade. Revista Eletrônica Direito e Política, Programa de Pós-Graduação Stricto Sensu em Ciência Jurídica da UNIVALI, Itajaí, v.12, n.3, $3^{\circ}$ quadrimestre de 2017. Disponível em: www.univali.br/direitoepolitica - ISSN 1980-7791

com os controles (internos e externos) incidentes, defenderam que a presença em reformas significativas", especialmente em matérias de direitos difusos e coletivos, possibilitou aos agentes ministeriais uma posição outrora reservada a políticos, desafiando a democracia tradicional majoritária, a divisão de poderes e a própria identidade das instituições de justiça, "evidenciando a adoção de padrão institucional caracterizado pela existência de atores e instituições com poder de veto." 55

Também há críticas por parte dos membros do Ministério Público Federal. Eis uma delas:

Panoeiro ${ }^{56}$ comenta sobre a edição de dezembro de 2015 , do boletim do Instituto Brasileiro de Ciências Criminais (IBCCrim) com editorial titulado "Todos contra a corrupção", dedicado à análise crítica das propostas compreendidas nas "Dez Medidas contra a Corrupção", o qual apresentou debate sobre as "propostas formuladas por um grupo de procuradores da República e, posteriormente, encampadas pelo próprio Ministério Público Federal." O autor ${ }^{57}$ aponta que a instigada crítica científica do boletim às propostas, não deu margem para fundamentar uma "dogmática àquelas propostas, dando por exaustivas as justificativas apresentadas" e com isso, "o renomado periódico se fez instrumento de um discurso único, sem contraponto, em detrimento do justo debate que deve permear o ambiente acadêmico".

Panoeiro ${ }^{58}$, ainda, afirma não defender esta ou aquela medida, mas ser uma

55 SOUZA, Luciano Machado de. Abdicação de accountability para arquivamento de inquérito ou peças de informação de infração penal pelo procurador-geral da república: afetação das dimensões democrática e republicana do estado democrático de direito. Tese (Doutorado em Direito). Faculdade de Direito. Universidade Federal do Paraná. Curitiba: UFPR, 2016, p.130.

56 PANOEIRO, José Maria. 0 delito de enriquecimento ilícito como estratégia para o combate à corrupção: considerações, críticas e reflexões político-criminais. Disponível em: http://www.dezmedidas.mpf.mp.br/apresentacao/artigos/crime-de-enriquecimento-ilicito-josepanoeiro.pdf/view. Acesso em: 29 out. 2016, p.8.

57 PANOEIRO, José Maria. 0 delito de enriquecimento ilícito como estratégia para o combate à corrupção: considerações, críticas e reflexões político-criminais. Disponível em: http://www.dezmedidas.mpf.mp.br/apresentacao/artigos/crime-de-enriquecimento-ilicito-josepanoeiro.pdf/view. Acesso em: 29 out. 2016, p.8.

58 PANOEIRO, José Maria. 0 delito de enriquecimento ilícito como estratégia para o combate 
SANTINI, Maria Carolina. O pacote anticorrupção e o debate sobre sua constitucionalidade. Revista Eletrônica Direito e Política, Programa de Pós-Graduação Stricto Sensu em Ciência Jurídica da UNIVALI, Itajaí, v.12, n.3, $3^{\circ}$ quadrimestre de 2017. Disponível em: www.univali.br/direitoepolitica - ISSN 1980-7791

constatação de que a exclusividade de um pensamento, "o boletim parece ter se distanciado do debate científico que se propunha a fomentar". Afirma o Procurador ${ }^{59}$ que não é o simples enriquecer de um funcionário público, "o comportamento desvalorado, mas seu enriquecer de alguma forma conectado, mesmo que por provas indiciárias, com o exercício inadequado da função pública", e que feita essa conexão, "estabelecer-se-ia o enriquecimento ilícito em razão da função pública, objeto de criminalização defendido na proposta examinada"60.

A seguir, expõe-se a terceira medida apresentada pelo Ministério Público Federal:

\section{A TERCEIRA MEDIDA: AUMENTO DAS PENAS E CRIME HEDIONDO PARA A CORRUPÇÃO DE ALTOS VALORES}

Lee $^{61}$ informa que o anteprojeto de lei proposto pelo Ministério Público Federal para o combate à corrupção estabelece a "majoração das penas privativas de liberdade em relação aos crimes praticados contra a Administração Pública, bem como a qualificação dos crimes em hediondos", fundamentado na vantagem ou no prejuízo proveniente do crime. Explica o autor ${ }^{62}$ o significado da palavra hediondo: abominável, asqueroso, horrível, repulsivo, repugnante, na qual se definiu quais

à corrupção: considerações, críticas e reflexões político-criminais. Disponível em: http://www.dezmedidas.mpf.mp.br/apresentacao/artigos/crime-de-enriquecimento-ilicito-josepanoeiro.pdf/view. Acesso em: 29 out. 2016, p.8-9.

59 PANOEIRO, José Maria. 0 delito de enriquecimento ilícito como estratégia para o combate à corrupção: considerações, críticas e reflexões político-criminais. Disponível em: http://www.dezmedidas.mpf.mp.br/apresentacao/artigos/crime-de-enriquecimento-ilicito-josepanoeiro.pdf/view. Acesso em: 29 out. 2016, p.24.

60 PANOEIRO, José Maria. 0 delito de enriquecimento ilícito como estratégia para o combate à corrupção: considerações, críticas e reflexões político-criminais. Disponível em: http://www.dezmedidas.mpf.mp.br/apresentacao/artigos/crime-de-enriquecimento-ilicito-josepanoeiro.pdf/view. Acesso em: 29 out. 2016, p.25.

61 LEE, Ju Hyeon. Anteprojeto de corrupção como crime hediondo à luz da Constituição da República Federativa do Brasil. Disponível em: http://www.dezmedidas.mpf.mp.br/apresentacao/artigos/corrupcao-como-crime-hediondo-juhyeon-lee.pdf. Acesso em: 29 out. 2016.

62 LEE, Ju Hyeon. Anteprojeto de corrupção como crime hediondo à luz da Constituição da República Federativa do Brasil. Disponível em: http://www.dezmedidas.mpf.mp.br/apresentacao/artigos/corrupcao-como-crime-hediondo-juhyeon-lee.pdf. Acesso em: 29 out. 2016, p.3. 
SANTINI, Maria Carolina. O pacote anticorrupção e o debate sobre sua constitucionalidade. Revista Eletrônica Direito e Política, Programa de Pós-Graduação Stricto Sensu em Ciência Jurídica da UNIVALI, Itajaí, v.12, n.3, $3^{\circ}$ quadrimestre de 2017. Disponível em: www.univali.br/direitoepolitica - ISSN 1980-7791

crimes representam esse sentimento no âmbito social, merecedores de maior rigor e reprimenda, com a aprovação da Lei no 8.072/1990.

Para Lee L3 $^{63}$ manifestações populares, ocorridas nos anos de 2013 e 2014 em todo o Brasil, demonstram "a necessidade de qualificação de determinados crimes contra a Administração Pública como hediondos". Indubitavelmente, a "população brasileira demanda uma punição rigorosa dessas condutas, por traduzirem um sentimento de repulsa e horror".

Pauperio ${ }^{64}$ afirma que há necessidade de renovar o processo penal: "precisamos de celeridade, que pode ser obtida a partir da simplificação dos procedimentos. Eliminar etapas desnecessárias é uma necessidade de correção do sistema". Alberto da Silva Franco ${ }^{65}$ aduz que falta noção adequada ao conceito de hediondo, o que acarreta um "desequilíbrio na ordem axiológica dos bens jurídicos a serem tutelados e uma banalização total do processo legislativo penal." O autor ${ }^{66}$ acrescenta não ser recomendável a inclusão de novos delitos na classificação dos hediondos, no atual momento de conflitos político-sociais no país. Desse modo, no anteprojeto de lei de iniciativa popular, conforme art.61, $\S 2^{\circ}$, da CF, pretende-se incluir nos crimes hediondos o peculato (art.312 e $\S 1^{\circ}$ do CP), a inserção de dados falsos em sistema de informações (art.313-A do CP), a concussão (art.316 do CP), excesso de exação qualificada pela apropriação (art.316, §20, do CP), corrupção passiva (art.317, do CP), corrupção ativa (art.333 do CP) quando a vantagem ou o prejuízo é igual ou superior a cem salários-mínimos vigentes ao tempo do fato e a estrutura de novo modelo penal aderida ao art.327-A do CP, dentre outros.

\footnotetext{
63 LEE, Ju Hyeon. Anteprojeto de corrupção como crime hediondo à luz da Constituição da República $\quad$ Federativa
http://www.dezmedidas.mpf.mp.br/apresentacao/artigos/corrupcao-como-crime-hediondo-ju-
hyeon-lee.pdf. Acesso em: 29 out. 2016, p.3.
}

64 PAUPERIO, Leonardo Tocchetto. Recursos penais e impunidade no Brasil. Disponível em: http://www.dezmedidas.mpf.mp.br/apresentacao/artigos/recursos-leo-pauperio-recursos-penais-eimpunidade-no-brasil.pdf. Acesso em: 29 out. 2016, p.1.

65 FRANCO, Alberto Silva. 6. corrupção como crime hediondo. Fábrica produtora de etiquetas. Boletim do Instituto Brasileiro de Ciências Criminais, ano 23, no 277, 2015, p.9.

66 FRANCO, Alberto Silva. 6. corrupção como crime hediondo. Fábrica produtora de etiquetas. Boletim do Instituto Brasileiro de Ciências Criminais, ano 23, no 277, 2015, p.9. 
SANTINI, Maria Carolina. O pacote anticorrupção e o debate sobre sua constitucionalidade. Revista Eletrônica Direito e Política, Programa de Pós-Graduação Stricto Sensu em Ciência Jurídica da UNIVALI, Itajaí, v.12, n.3, $3^{\circ}$ quadrimestre de 2017. Disponível em: www.univali.br/direitoepolitica - ISSN 1980-7791

Franco ${ }^{67}$ afirma que a proposta é desarrazoada, por se tratar de uma invasão indevida do sistema punitivo estadunidense no ordenamento brasileiro, o qual não comporta flexibilidade - dada ocorrência de vantagem ou desvantagem, elementos que devem ser valorados no art.59 do CP - cuja presença pode ensejar atividade corruptora de maior proporção, tendo em vista que um real a menos no valor total reduz de três anos a pena mínima do delito responsabilizado. Conclui o autor ${ }^{68}$ que se atinge o agravo ao princípio constitucional da proporcionalidade, sufocando os tipos penais com legislação extravagante, que os transfere para o reino da hediondez.

Streck ${ }^{69}$ afirma que, sobre a transformação da corrupção em crime hediondo seria uma noção mágica de tornar a pena da corrupção mais grave que a do homicídio, nas hipóteses de desvio a partir de cem salários mínimos. 0 autor ${ }^{70}$ propõe que no lugar de procurar soluções ilusionistas, ostentadas por correligionários do direito penal máximo, crentes que tornar a lei mais rigorosa "pode mudar a realidade, não seria melhor lutar para ampliar a democratização do nosso sistema político?" Streck ${ }^{71}$ explica que o punitivismo nunca foi a melhor solução, exemplificando com o caso da Inglaterra do século XVIII, em que se atribuiu ao furto a pena de morte por enforcamento, feito em praça pública, e que o dia em que mais carteiras se furtaram, foi o da execução.

Tratou-se de expor na terceira medida que pretende tipificar a corrupção como crime hediondo. A quarta medida cuida dos recursos processuais penais.

67 FRANCO, Alberto Silva. 6. corrupção como crime hediondo. Fábrica produtora de etiquetas. Boletim do Instituto Brasileiro de Ciências Criminais, ano 23, n 277, 2015, p.9.

68 FRANCO, Alberto Silva. 6. corrupção como crime hediondo. Fábrica produtora de etiquetas. Boletim do Instituto Brasileiro de Ciências Criminais, ano 23, no 277, 2015, p.9.

69 STRECK, Lenio Luiz. O pacote anticorrupção do Ministério Público e o fator Minority Report. Senso incomum. Conjur. 03/03/2016. Disponível em: http://www.conjur.com.br/2016-mar03/senso-incomum-pacote-anticorrupcao-mpf-fator-minority-report. Acesso em: 19 set. 2016.

70 STRECK, Lenio Luiz. O pacote anticorrupção do Ministério Público e o fator Minority Report. Senso incomum. Conjur. 03/03/2016. Disponível em: http://www.conjur.com.br/2016-mar03/senso-incomum-pacote-anticorrupcao-mpf-fator-minority-report. Acesso em: 19 set. 2016.

71 STRECK, Lenio Luiz. O pacote anticorrupção do Ministério Público e o fator Minority Report. Senso incomum. Conjur. 03/03/2016. Disponível em: http://www.conjur.com.br/2016-mar03/senso-incomum-pacote-anticorrupcao-mpf-fator-minority-report. Acesso em: 19 set. 2016. 
SANTINI, Maria Carolina. O pacote anticorrupção e o debate sobre sua constitucionalidade. Revista Eletrônica Direito e Política, Programa de Pós-Graduação Stricto Sensu em Ciência Jurídica da UNIVALI, Itajaí, v.12, n.3, $3^{\circ}$ quadrimestre de 2017. Disponível em: www.univali.br/direitoepolitica - ISSN 1980-7791

\section{A QUARTA MEDIDA CONTRA A CORRUPÇÃO: EFICIÊNCIA DOS RECURSOS NO PROCESSO PENAL}

Prado $^{72}$ assume que ambas as propostas, quais sejam: o recurso manifestamente protelatório e a de execução provisória da pena, não são passíveis de se alinhavar em um simples artigo a infinidade de problemas teóricos, dificuldade reveladora de que "temas e problemas complexos não se resolvem de maneira simplória"; "há profunda distinção entre pragmatismo e versão (correspondente a uma visão parcial ou tendenciosa) de determinada questão. As soluções em uma só perspectiva são problemáticas e é isso que a dogmática penal busca corrigir. 0 autor $^{73}$ então convoca ao amadurecimento do debate. O problema da importação cultural, isto é, a tentativa de trazer para uma realidade experiências oriundas de uma cultura diversa.

Aury Lopes Jr. ${ }^{74}$ denominou as Dez Medidas como o "pacotaço-punitivista-do-MPF", e chama as medidas de casuísticas e populistas. Afirma se tratar de um movimento oportunista, com um engodo aproveitador da revolta contra a corrupção, que afetará não apenas os crimes de corrupção como todos os restantes, além dos processos penais. O impacto penal, processual e penitenciário não está sendo medido. Declara que são medidas vendidas, excessivas e desnecessárias que afetarão apenas os acusados descamisados. Há consenso entre os juristas de que o CPP deva ser revisado, mas não é disso que se trata o pacote do MPF, e sim de um vale-tudo-punitivista. $O$ autor ${ }^{75}$ questiona qual seria a diferença, nesse contexto, entre a manifestação protelatória e a utilização da ampla defesa? Outras propostas radicais: alteração e limitação do habeas corpus e possibilidade de

72 PRADO, Geraldo. O trânsito em julgado da decisão condenatória. Boletim do Instituto Brasileiro de Ciências Criminais, ano 23, no 277, 2015, p.10.

73 PRADO, Geraldo. O trânsito em julgado da decisão condenatória. Boletim do Instituto Brasileiro de Ciências Criminais, ano 23, no 277, 2015, p.10.

74 LOPES JR, Aury. 9. Revisão dos recursos no CPP. Mudanças no Sistema Recursal: só esqueceram de avisar a Constituição. Boletim do Instituto Brasileiro de Ciências Criminais, ano 23, no 277, 2015, p.12.

75 LOPES JR, Aury. 9. Revisão dos recursos no CPP. Mudanças no Sistema Recursal: só esqueceram de avisar a Constituição. Boletim do Instituto Brasileiro de Ciências Criminais, ano 23, no 277, 2015, p.13. 
SANTINI, Maria Carolina. O pacote anticorrupção e o debate sobre sua constitucionalidade. Revista Eletrônica Direito e Política, Programa de Pós-Graduação Stricto Sensu em Ciência Jurídica da UNIVALI, Itajaí, v.12, n.3, $3^{\circ}$ quadrimestre de 2017. Disponível em: www.univali.br/direitoepolitica - ISSN 1980-7791

execução provisória da pena.

Streck $^{76}$, sobre a restrição de recursos e fragilização do Habeas Corpus, o MPF reduz os recursos "com um discurso preocupado com a eficiência da Justiça". O autor $^{77}$ pondera que há semelhanças com a época ditatorial, que por uma "boa causa se ataca o Estado (Democrático?) de Direito. Afinal, as alterações servirão para caçar somente os homens maus que habitam a república". Então, explica Streck $^{78}$ que o MPF resgataria o fundamento dos militares a favor da contenção do habeas corpus: "estamos aperfeiçoando o sistema processual brasileiro. Ora, o Habeas Corpus já foi melhor há mais de mil anos." O autor ${ }^{79}$ afirma, ainda, que a proposta do MPF veda a concessão de "Habeas Corpus de ofício; em caráter liminar; quando houver supressão de instância; para se discutir nulidade, trancar investigação ou processo". Ademais, "condiciona sua concessão à prévia requisição de informações ao promotor natural da instância de origem." Informa Streck ${ }^{80}$ que há decretação do trânsito em julgado para os casos de recursos manifestamente protelatórios, e comenta ser inacreditável que "num país marcado pela discricionariedade judicial, querem que o trânsito em julgado da ação possa ser declarado monocraticamente". O autor ${ }^{81}$ pondera que poderia então ser criada uma PEC para amarrar o réu e jogá-lo na água, condicionando sua inocência, pela

76 STRECK, Lenio Luiz. O pacote anticorrupção do Ministério Público e o fator Minority Report. Senso incomum. Conjur. 03/03/2016. Disponível em: http://www.conjur.com.br/2016-mar03/senso-incomum-pacote-anticorrupcao-mpf-fator-minority-report. Acesso em: 19 set. 2016.

77 STRECK, Lenio Luiz. O pacote anticorrupção do Ministério Público e o fator Minority Report. Senso incomum. Conjur. 03/03/2016. Disponível em: http://www.conjur.com.br/2016-mar03/senso-incomum-pacote-anticorrupcao-mpf-fator-minority-report. Acesso em: 19 set. 2016.

78 STRECK, Lenio Luiz. O pacote anticorrupção do Ministério Público e o fator Minority Report. Senso incomum. Conjur. 03/03/2016. Disponível em: http://www.conjur.com.br/2016-mar03/senso-incomum-pacote-anticorrupcao-mpf-fator-minority-report. Acesso em: 19 set. 2016.

79 STRECK, Lenio Luiz. O pacote anticorrupção do Ministério Público e o fator Minority Report. Senso incomum. Conjur. 03/03/2016. Disponível em: http://www.conjur.com.br/2016-mar03/senso-incomum-pacote-anticorrupcao-mpf-fator-minority-report. Acesso em: 19 set. 2016.

80 STRECK, Lenio Luiz. O pacote anticorrupção do Ministério Público e o fator Minority Report. Senso incomum. Conjur. 03/03/2016. Disponível em: http://www.conjur.com.br/2016-mar03/senso-incomum-pacote-anticorrupcao-mpf-fator-minority-report. Acesso em: 19 set. 2016.

81 STRECK, Lenio Luiz. O pacote anticorrupção do Ministério Público e o fator Minority Report. Senso incomum. Conjur. 03/03/2016. Disponível em: http://www.conjur.com.br/2016-mar03/senso-incomum-pacote-anticorrupcao-mpf-fator-minority-report. Acesso em: 19 set. 2016. 
SANTINI, Maria Carolina. O pacote anticorrupção e o debate sobre sua constitucionalidade. Revista Eletrônica Direito e Política, Programa de Pós-Graduação Stricto Sensu em Ciência Jurídica da UNIVALI, Itajaí, v.12, n.3, $3^{\circ}$ quadrimestre de 2017. Disponível em: www.univali.br/direitoepolitica - ISSN 1980-7791

sua sobrevivência ao flutuar; ou culpabilidade, se afundar.

Resta, no presente momento, seguir para a medida no 5 , a qual exibe uma celeridade nas ações de improbidade administrativa.

\section{A QUINTA MEDIDA CONTRA A CORRUPÇÃO: CELERIDADE NAS AÇÕES DE IMPROBIDADE ADMINISTRATIVA}

As ações de improbidade tem duas causas: a duplicação de sua fase inicial; e a concorrência de casos complexos com outros mais simples que tem prioridade em varas sobrecarregadas. Ademais, "não há ainda um diagnóstico público das ações de improbidade, nem uma rotina para que o próprio Judiciário busque soluções". 82 A proposta abarca três alterações na Lei no 8.429/92. Altera-se, preliminarmente, a redação do art. 17 para agilizar a primeira fase do procedimento, atualmente com "duplicação de etapa ineficiente e desnecessária, consistente na existência de duas oportunidades sucessivas para apresentação de defesa"83. Passou-se a adotar analogicamente o arquétipo da Reforma do Código de Processo Penal, que protege a liberdade e permite apenas uma defesa, da qual após o juiz possa eliminar a ação, caso falte fundamento para prosseguir. Assim, evita-se resposta a "uma ação de improbidade injustificada e, ao mesmo, tempo evita repetição desnecessária de atos. A recorribilidade da decisão que recebe a ação fica preservada mediante o instituto do agravo retido, a não mais de instrumento. ${ }^{84}$

Afora isso, propõe-se a criação de varas, câmaras e turmas especializadas "para julgar ações de improbidade administrativa e ações decorrentes da lei

\footnotetext{
82 Ministério Público Federal. As dez medidas contra a corrupção: 5. Celeridade nas ações de improbidade administrativa. Disponível em: http://www.dezmedidas.mpf.mp.br/apresentacao/conheca-as-medidas/medida-5. Acesso em: 22 jul. 2017.

83 Ministério Público Federal. As dez medidas contra a corrupção: 5. Celeridade nas ações de improbidade administrativa. Disponível http://www.dezmedidas.mpf.mp.br/apresentacao/conheca-as-medidas/medida-5. Acesso em: 22 jul. 2017.

${ }^{84}$ Ministério Público Federal. As dez medidas contra a corrupção: 5. Celeridade nas ações de improbidade administrativa. Disponível em: http://www.dezmedidas.mpf.mp.br/apresentacao/conheca-as-medidas/medida-5. Acesso em: 22 jul. 2017.
} 
SANTINI, Maria Carolina. O pacote anticorrupção e o debate sobre sua constitucionalidade. Revista Eletrônica Direito e Política, Programa de Pós-Graduação Stricto Sensu em Ciência Jurídica da UNIVALI, Itajaí, v.12, n.3, $3^{\circ}$ quadrimestre de 2017. Disponível em: www.univali.br/direitoepolitica - ISSN 1980-7791

anticorrupção", para evitar que o "julgamento de ações de improbidade mais complexas, seja preterido pelo julgamento de casos mais simples, ainda que menos relevantes, os quais são preferidos como forma de dar vazão ao trabalho em varas já sobrecarregadas"85. Por derradeiro, sugere-se o acréscimo do art. 17A na Lei no 8.429/92 "para permitir que o Ministério Público Federal firme acordo de leniência, à luz de previsão do acordo de colaboração que já existe no âmbito penal". 86

O editorial do Boletim do IBCCRIM"87 aponta que "não somente de propostas descabidas é formado o pacote de medidas do Ministério Público. Há as alvissareiras, sem dúvida". Um exemplo disso é a criação de regras de accountability dos tribunais, instrumento necessário para modernizar e avançar o sistema normativo vigente. Souza ${ }^{88}$, em sua tese acerca da accountability, afirma que:

A sujeição ao Direito (rule of law), contudo, é o ponto irregular de convergência que possibilita igualar os cidadãos nos momentos decisórios (democracia), como nos momentos de sujeição às normas (republicanismo), e também na proteção de liberdades e garantias (liberalismo) declaração de igualdade, de proteção de liberdades e garantias. [...] A falta de sujeição (nonaccountability) dos agentes públicos à lei e priorização do interesse público afeta a dimensão republicana da poliarquia; a usurpação ilegal de atribuição e a obtenção de vantagem ilícita ("corrupção"), que podem afetar os

\footnotetext{
85 Ministério Público Federal. As dez medidas contra a corrupção: 5. Celeridade nas ações de improbidade administrativa.
} http://www.dezmedidas.mpf.mp.br/apresentacao/conheca-as-medidas/medida-5. Acesso em: 22 jul. 2017.

${ }^{86}$ Ministério Público Federal. As dez medidas contra a corrupção: 5. Celeridade nas ações de improbidade administrativa. Disponível em: http://www.dezmedidas.mpf.mp.br/apresentacao/conheca-as-medidas/medida-5. Acesso em: 22 jul. 2017.

87 Boletim do Instituto Brasileiro de Ciências Criminais, Ano 23, no 277, 2015. Disponível em: http://www.ibccrim.org.br/site/boletim/pdfs/Boletim277.pdf. Acesso em: 06 nov. 2016.

88 SOUZA, Luciano Machado de. Abdicação de accountability para arquivamento de inquérito ou peças de informação de infração penal pelo procurador-geral da república: afetação das dimensões democrática e republicana do estado democrático de direito. Tese (Doutorado em Direito). Faculdade de Direito. Universidade Federal do Paraná. Curitiba: UFPR, 2016, p.162. 
SANTINI, Maria Carolina. O pacote anticorrupção e o debate sobre sua constitucionalidade. Revista Eletrônica Direito e Política, Programa de Pós-Graduação Stricto Sensu em Ciência Jurídica da UNIVALI, Itajaí, v.12, n.3, $3^{\circ}$ quadrimestre de 2017. Disponível em: www.univali.br/direitoepolitica - ISSN 1980-7791

procedimentos de accountability, impactam a dimensão republicana. ${ }^{89}$

Ao expor as razões do MPF para a propositura das 10 medidas, é pertinente citar a conclusão de Diniz ${ }^{90}$, sobre as mazelas estruturais sofridas pela Administração Pública brasileira, apesar da constatação de diversos avanços. Entretanto, segundo o autor ${ }^{91}$, "verifica-se que o aprofundamento da democracia está diretamente relacionado ao pleno exercício dos mecanismos de controle, os quais recomendam a reorganização do Ministério Público, estratégias adequadas de atuação", além de "inovações legislativas em diversos segmentos. É o que se espera que se efetive, para que se atinja a situação ideal de proteção eficiente do patrimônio público." Souza ${ }^{92}$ aponta que há demonstração da responsabilidade das autoridades no combate ao abuso de poder e correlata promoção da igualdade de todos perante a lei e da responsabilidade dos agentes públicos em combater o abuso do poder. Segundo o autor ${ }^{93}$, o MPF já conseguiu mobilizar a opinião pública a apoiar projetos de lei dedicados ao combate da corrupção.

A medida número cinco trouxe ao debate a possibilidade de melhora no sistema da Administração Pública, elogiada pelo boletim do IBCCrim.

89 O'DONNELL, Guillermo. Horizontal accountability and new polyarchies. Kellogg Institute for International Studies. Working paper n. 253, Indiana, abr-1998. Disponível em: <https://kellogg.nd.edu/publications/workingpapers/WPS/253.pdf>. Acesso em: 5 nov.2016, 3-11; p.16.

90 DINIZ, Cláudio Smirne. Ministério Público: a proteção eficiente na área do controle do patrimônio público. In: CAMBI, Eduardo; GUARAGNI, Fábio André (org). Ministério Público e princípio da proteção eficiente. São Paulo: Almedina, 2016, p.35.

91 DINIZ, Cláudio Smirne. Ministério Público: a proteção eficiente na área do controle do patrimônio público. In: CAMBI, Eduardo; GUARAGNI, Fábio André (org). Ministério Público e princípio da proteção eficiente. São Paulo: Almedina, 2016, p.35.

92 SOUZA, Luciano Machado de. Abdicação de accountability para arquivamento de inquérito ou peças de informação de infração penal pelo procurador-geral da república: afetação das dimensões democrática e republicana do estado democrático de direito. Tese (Doutorado em Direito). Faculdade de Direito. Universidade Federal do Paraná. Curitiba: UFPR, 2016, p.131.

93 SOUZA, Luciano Machado de. Abdicação de accountability para arquivamento de inquérito ou peças de informação de infração penal pelo procurador-geral da república: afetação das dimensões democrática e republicana do estado democrático de direito. Tese (Doutorado em Direito). Faculdade de Direito. Universidade Federal do Paraná. Curitiba: UFPR, 2016, p. 174. 
SANTINI, Maria Carolina. O pacote anticorrupção e o debate sobre sua constitucionalidade. Revista Eletrônica Direito e Política, Programa de Pós-Graduação Stricto Sensu em Ciência Jurídica da UNIVALI, Itajaí, v.12, n.3, $3^{\circ}$ quadrimestre de 2017. Disponível em: www.univali.br/direitoepolitica - ISSN 1980-7791

\section{CONSIDERAÇÕES FINAIS}

Este artigo versou sobre as medidas contra a corrupção, elaboradas e recomendadas pelo Ministério Público Federal, apontamentos em sua defesa e críticas em seu desfavor. A discussão fundamentou-se no modo como foram feitas as propostas, incluindo redução de garantias constitucionais.

Acerca das cinco primeiras medidas trazidas no Projeto de Lei no 4.850/2016, pode-se afirmar seguinte: originada do sistema norte-americano, a primeira medida, para prevenir a corrupção, estabeleceu o teste de integridade e o informante confidencial - já utilizado como anônimo, pela jurisprudência do Supremo Tribunal Federal, com denominação considerada equivocada. Proteger a identidade do informante auxiliaria nas delações e na obtenção de informações sobre crimes.

A segunda medida propôs criminalizar o enriquecimento ilícito de agentes públicos. Recebe crítica porque haveria presunção de que a não comprovação da origem dos bens, configuraria o ilícito. O aumento injustificado de patrimônio de funcionário público é criminalizado em diversos países. Considerando a não comprovação dos atos, fere-se o princípio da presunção de inocência, do mesmo modo que o da culpabilidade, como prova indireta da corrupção. Devido à dificuldade em punir as condutas pelo crime de corrupção, justificar-se-ia a medida ao MPF, além de ser exercício inadequado de função pública, embora seja criticada por ser meio de prova indireta.

A terceira medida optou pela majoração das penas e a tipificação como crime hediondo - tido como abominável e repugnante, sendo representativo da repulsa em âmbito social - para a corrupção de altos valores. Muito criticada pelos criminalistas, a medida pretendeu o aumento das penas em relação a crimes praticados contra a Administração Pública e incluir como hediondo os crimes de: peculato; inserção de dados falsos em sistema de informações; concussão; apropriação; corrupção ativa e passiva. Há, ainda, questionamentos quanto à razoabilidade desta proposta, atingindo o princípio da proporcionalidade, a qual seria representativa de um direito penal máximo que rememora o século XVIII. 
SANTINI, Maria Carolina. O pacote anticorrupção e o debate sobre sua constitucionalidade. Revista Eletrônica Direito e Política, Programa de Pós-Graduação Stricto Sensu em Ciência Jurídica da UNIVALI, Itajaí, v.12, n.3, $3^{\circ}$ quadrimestre de 2017. Disponível em: www.univali.br/direitoepolitica - ISSN 1980-7791

A quarta medida trouxe mecanismos para maximizar a eficiência dos recursos no processo penal. A recomendação teve por fulcro agilizar os processos, mas obteve insatisfação de juristas acerca porque prejudicaria direitos dos réus. Tratou do recurso manifestamente protelatório e da execução provisória da pena. Vedou habeas corpus, de ofício ou em liminar, cuja concessão deveria estar condicionada a prévio parecer de um promotor natural, da instância de origem. Com isso, haveria a possibilidade de decretar trânsito em julgado para casos com recursos manifestamente protelatórios, em decisão monocrática.

A quinta medida buscou imprimir celeridade nas ações de improbidade administrativa. Essa proposta decorreu do sistema de accountabilities e apontou para a sobrecarga nas varas. Além disso, visaria evitar a repetição de atos que são desnecessários, e propôs a criação de varas, câmaras e turmas especializadas para ações de improbidade administrativa. Eis a única, das cinco medidas elencadas, em que não foram encontradas críticas; ao contrário, gerou somente elogios.

\section{REFERÊNCIAS DAS FONTES CITADAS}

ANTUNES, Ruy Braga Ricardo. Os dias que abalaram o Brasil: as as rebeliões de junho, julho de 2013. Disponível em: http://www.periodicoseletronicos.ufma.br/index.php/rppublica/article/view/2694. Acesso em: 26 jun. 2017.

IBCCRIM, Boletim do Instituto Brasileiro de Ciências Criminais, Ano 23, no 277, 2015.2 Disponível em: http://www.ibccrim.org.br/site/boletim/pdfs/Boletim277.pdf. Acesso em: 06 nov. 2016.

CALABRICH, Bruno. Teste de integridade: aplicação, críticas e constitucionalidade. Disponível em: http://www.dezmedidas.mpf.mp.br/apresentacao/artigos/teste-de-integridadebruno-calabrich.pdf/view. Acesso em: 29 out. 2016, p.2.

COSTA, Pedro Jorge do Nascimento. o crime de enriquecimento ilícito: compatibilidade com o ordenamento jurídico. Disponível em: http://www.dezmedidas.mpf.mp.br/apresentacao/artigos/crime-deenriquecimento-ilicito-pedro-jorge.pdf/view. Acesso em: 29 out. 2016, p.2.

CRUZ, Flavio Antonio da. Teste de integridade e sigilo da fonte: exame crítico. Boletim do Instituto Brasileiro de Ciências Criminais, ano 23, no 277, 2015, p.5. 
SANTINI, Maria Carolina. O pacote anticorrupção e o debate sobre sua constitucionalidade. Revista Eletrônica Direito e Política, Programa de Pós-Graduação Stricto Sensu em Ciência Jurídica da UNIVALI, Itajaí, v.12, n.3, $3^{\circ}$ quadrimestre de 2017. Disponível em: www.univali.br/direitoepolitica - ISSN 1980-7791

DALLAGNOL, Deltan Martinazzo. Informantes confidenciais e anônimos: perspectivas para atuação mais eficiente do Estado a partir de uma análise comparativa do tratamento jurídico nos EUA e no Brasil. In: CAMBI, Eduardo; GUARAGNI, Fábio André (org). Ministério Público e princípio da proteção eficiente. São Paulo: Almedina, 2016, p.40.

DINIZ, Cláudio Smirne. Ministério Público: a proteção eficiente na área do controle do patrimônio público. In: CAMBI, Eduardo; GUARAGNI, Fábio André (org). Ministério Público e princípio da proteção eficiente. São Paulo: Almedina, 2016, p.35.

FRANCO, Alberto Silva. 6. corrupção como crime hediondo. Fábrica produtora de etiquetas. Boletim do Instituto Brasileiro de Ciências Criminais, ano 23, no 277, 2015, p.9.

GRECO, Luís. Reflexões provisórias sobre o crime de enriquecimento ilícito. Boletim do Instituto Brasileiro de Ciências Criminais, ano 23, no 277, 2015, p.7.

GUAlTIERI, Lucas de Morais; CERQUeIRA, Marcelo Malheiros. Pelo MP: o informante confidencial como instrumento de combate à corrupção. Disponível em: http://jota.info/pelo-mp-o-informante-confidencial-comoinstrumento-de-combate-corrupcao. Acesso em: 29 out. 2016.

LEE, Ju Hyeon. Anteprojeto de corrupção como crime hediondo à luz da Constituição da República Federativa do Brasil. Disponível em: http://www.dezmedidas.mpf.mp.br/apresentacao/artigos/corrupcao-como-crimehediondo-ju-hyeon-lee.pdf. Acesso em: 29 out. 2016.

LOPES JR, Aury. 9.Revisão dos recursos no CPP. Mudanças no Sistema Recursal: só esqueceram de avisar a Constituição. Boletim do Instituto Brasileiro de Ciências Criminais, ano 23, no 277, 2015, p.12.

MEDEIROS, Mário Alves. Preservação do sigilo da fonte em casos de corrupção: medida necessária, constitucional e correta. Disponível em: http://www.dezmedidas.mpf.mp.br/apresentacao/artigos/sigilo-da-fonte-marioalves-medeiros.pdf., p.2.

Ministério Público Federal. As dez medidas contra a corrupção: 5. Celeridade nas ações de improbidade administrativa. Disponível em: http://www.dezmedidas.mpf.mp.br/apresentacao/conheca-as-medidas/medida5. Acesso em: 22 jul. 2017.

O'DONNELL, Guillermo. Horizontal accountability and new polyarchies. Kellogg Institute for International Studies. Working paper n. 253, Indiana, abr.1998.

em: <https://kellogg.nd.edu/publications/workingpapers/WPS/253.pdf>. Acesso em: 5 nov.2016, 3-11; p.16.

PANOEIRO, José Maria. O delito de enriquecimento ilícito como estratégia 
SANTINI, Maria Carolina. O pacote anticorrupção e o debate sobre sua constitucionalidade. Revista Eletrônica Direito e Política, Programa de Pós-Graduação Stricto Sensu em Ciência Jurídica da UNIVALI, Itajaí, v.12, n.3, $3^{\circ}$ quadrimestre de 2017. Disponível em: www.univali.br/direitoepolitica - ISSN 1980-7791

para o combate à corrupção: considerações, críticas e reflexões políticocriminais.

Disponível

em:

http://www.dezmedidas.mpf.mp.br/apresentacao/artigos/crime-de-

enriquecimento-ilicito-jose-panoeiro.pdf/view. Acesso em: 29 out. 2016, p.6.

PAUPERIO, Leonardo Tocchetto. Recursos penais e impunidade no Brasil. Disponível em: http://www.dezmedidas.mpf.mp.br/apresentacao/artigos/recursos-leo-pauperiorecursos-penais-e-impunidade-no-brasil.pdf. Acesso em: 29 out. 2016, p.1.

PRADO, Geraldo. O trânsito em julgado da decisão condenatória. Boletim do Instituto Brasileiro de Ciências Criminais, ano 23, n 277, 2015, p.10.

PUNCH, Maurice. Police corruption: desviance, accountability and reform in policing. New york/London: Routhledge, 2011, p.37 apud GUALTIERI, Lucas de Morais; CERQUEIRA, Marcelo Malheiros. Pelo MP: o informante confidencial como instrumento de combate à corrupção. Disponível em: http://jota.info/pelo-mp-o-informante-confidencial-como-instrumento-decombate-corrupcao. Acesso em: 29 out. 2016.

SOUZA, Luciano Machado de. Abdicação de accountability para arquivamento de inquérito ou peças de informação de infração penal pelo procuradorgeral da república: afetação das dimensões democrática e republicana do estado democrático de direito. Tese. Curitiba: UFPR, 2016, p.130.

STRECK, Lenio Luiz. Lenio Streck: pacote retroage mais de mil anos. ZH. Disponível em: http://zh.clicrbs.com.br/rs/opiniao/noticia/2016/02/lenio-streckpacote-retroage-mais-de-mil-anos-4984832.html. Acesso em: 19 set. 2016.

O pacote anticorrupção do Ministério Público e o fator Minority Report.

Senso incomum. Revista Consultor Jurídico. Disponível em: http://www.conjur.com.br/2016-mar-03/senso-incomum-pacote-anticorrupcaompf-fator-minority-report. Acesso em: 19 set. 2016.

Submetido em: agosto de 2017

Aprovado em: novembro de 2017 